\title{
Post-Fire Vegetation Recovery in Elwasita Area of Al-Jabal Al-Akhdar-Libya - Based on Remote Sensing Information
}

\author{
Moussa J. Masoud \\ Department of Forestry and Rangeland, Faculty of Natural Resources and Environmental Sciences, \\ Omar Al-Mukhtar University, Al Bayada, Libya.
}

Received: 16 August 2021 / Accepted: 16 November 2021

Doi: https://doi.org/10.54172/mjsc.v36i4.588

\begin{abstract}
Satellite-based remote sensing technologies and Geographical Information Systems (GIS) present operable and cost-effective solutions for mapping fires and observing post-fire regeneration. Elwasita wildfire, which occurred during April and May in 2013 in Libya, was selected as a study site. This study aims to monitor vegetation recovery and investigate the relationship between vegetation recovery and topographic factors by using multi-temporal spectral indices together with topographical factors. Landsat 8 (OLI and TIRS) images from different data were obtained which were for four years; April 2013, June 2014, July 2015, and July 2016, to assess the related fire severity using the widely-used Normalized Burn Ratio (NBR). Normalized difference Vegetation Index (NDVI) was used to determine vegetation regeneration dynamics for four consecutive years. Also, the state of damage, vegetation recovery and, damage dimensions about the burned area were capable of being effectively detected using the result of supervised classification of Landsat satellite images. In addition, aspect, slope, and altitude images derived from Digital Elevation Model (DEM) were used to determine the fire severity of the study area. The results have found that it could be possible to figure out the degree of vegetation recovery by calculating the NDVI and NBR using Landsat 8 OLI and TIRS images. Analysis showed that it mainly oriented towards the northwest (47\%), north (29\%), and northeast (12\%). The statistical analysis showed that fire was concentrated on the incline by $76 \%$, and the most affected areas are those between $200 \mathrm{~m}-450 \mathrm{~m}$ above sea level, with a percentage of $80 \%$. It is expected that the information can be acquired by various satellite data and digital forests. This study serves as a window to an understanding of the process of fire severity and vegetation recovery that is vital in wildfire management systems.
\end{abstract}

Keywords: GIS, NDVI, NBR, Satellite images.

\section{INTRODUCTION}

Fire is a natural factor that appears in all forest ecosystems and affects its numerous functions such as; adjusting plant succession and wildlife homeland, recycling nutrients, keeping biological diversity, decreasing biomass, and monitoring insect and disease populations. Therefore, fire can destroy trees and understory plants. Local species historically adjusted to fire and had a high regeneration capability. But since Homo sapiens first learned how to use fire, this balance was destroyed and the majority of forest fire has been of anthropogenic origin result- ing in different tragic problems threatening the life of its main cause (Tishkov, 2004). The passive influences include air and water pollution, soil losses, destroyed biodiversity, desertification, soil corrosion, affecting human health and safety, as well as loss of human life. The Mediterranean basin is one of the world's biodiversity hotspots (Alacantara, 2010), where numerous civilizations over history relied on its forest resources for their cultural, economic, social, and esthetic service. However, every year fires damage millions of hectares of these surfaces (Maheras, 2002). This study serves as a window to an understanding of the process of fire 
severity and vegetation recovery that is vital in wildfire management systems (Maheras, 2002). Fire is a considerable factor in the framework of many communities worldwide (Bond et al., 2005). There is an argument that fire was recurrent over the late Quaternary in the Mediterranean region (Carrion et al., 2003). Fires were recurrent much previously as many species have gained adaptive mechanisms to continue and regenerate after recurrent fires (Pausas \& Verdú, 2005; Pausas, 2004). Mediterranean region biodiversity has been composition according to the various fire regimes. Therefore, it is obvious that in the Mediterranean region, fires are natural, they have happened for millennia, and plants can overcome them. In this case, fires ought not to be considered an ecological disaster but rather a part of the natural process. However, few studies suggest that current fire regimes may cause disasters in the sense of inducing sudden community changes or significant soil erosion (Arnan et al., 2007; Kazanis \& Arianoutsou, 2004; Rodrigo et al., 2004).

Since the mid-eighties of the last century, numerous remote sensing applications have been preceding to assess fire severity on local and regional ecosystems. Some studies found fire caused vegetation shift measured by satellite sensors, whereas additional recent studies have discussed linking ecological measures to fireinduced physical changes on the land surface (Jakubauskas et al., 1990; White et al., 1996). When a plant is burned, a decrease in visibleto-near-infrared surface reflectance correlates with the charring and of vegetation (Eva \& Lambin, 1998; Trigg \& Flasse, 2000). At finer spatial resolutions, the burning of a large area of vegetation may, in some situations, lead to a rise in surface reflectance because of the deposition of white ash (Landmann, 2003; Roy \& Landmann, 2005; Smith \& Hudak, 2005; Smith et al., 2005). This is usually joined by an increase in the short wave infrared reflectance and brightness temperatures, which is imputed to the many effects of rising soil exposure, a rise in radiation absorption by charred vegeta- tion, and reduced evapotranspiration comparative to the pre-fire green vegetation (Eva \& Lambin, 1998; Smith et al., 2005; Stroppiana et al., 2002). The degree of post-fire change may vary depending on vegetation type, annual differences in growing season weather, and overall time since fire. For this reason, stratification among vegetation types, comparison of images with similar vegetation phenology, and image differencing techniques including pre-fire, immediate post-fire and 1-year-post-fire images have been recommended to assess fire effects and ecological change (Cocke et al., 2005; White et al., 1996). Moreover, canopy mortality, ground charring, and changes in soil color caused by fire; can be easily detected, provided sensors have an adequate spatial and spectral resolution (White et al., 1996).

Presently, remote sensing technology and GIS in the mapping and classification of natural resources are widely available. Using remote sensing to classify and analyze burned areas require some information on the land cover disturbance effect on the reflection of electromagnetic energy (White et al., 1996). After a dry season, and a severe shortage of rainfall and an increase of hot southern wind, fires erupted in Elwasita at north of Al-Bayda city in Al-Jabal Al-Akhdar region, during the months of April and May in 2013, which led to the destruction of vast areas of forest up to thousands of hectares (Masoud \& Alajeel 2016).

The main objective of this study is to detect vegetation recovery following fire using Landsat 8 (OLI and TIRS) images and investigate the relationship between fire occurrences and topographic factors: altitude, slope, and aspect using GIS techniques. In this investigation, burn severity and vegetation recovery were assessed by using NDVI and NBR indices.

\section{MATERIALS AND METHODS}

Study Area: The Elwasita area is located in the Al-Jabal Al-Akhdar region on the northeast coast of Libya (Figure 1). Al-Jabal Al-Akhdar extends from a latitude of $32^{\circ} 00^{\prime}$ to $33^{\circ} 00^{\prime} \mathrm{N}$ 
and longitude of $20^{\circ} 00^{\prime}$ to $23^{\circ} 00^{\prime} \mathrm{E}$. With Libya's highest rainfall $(600 \mathrm{~mm})$, the Al-Jabal AlAkhdar region incorporates areas of intensive agriculture on plains and valley bottoms, and open woodland and shrubland on steep ravines and terra rosa slopes (Masoud, 2015).

Location map of Elwasita Area.

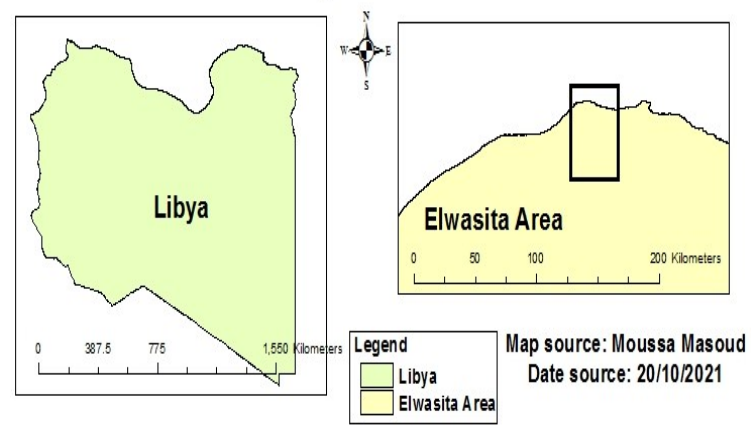

Figure: (1). Elwasita area in Al-Jabal Al-Akhdar, Libya.

Satellite imagery: A set of images Landsat 8 OLI and TIRS (with 11 spectral bands and $30 \mathrm{~m}$ spatial resolution) from different data, which were for four years from April in 2013 to July in 2016, were applied from Landsat 8 (OLI and TIRS) (http://glovis.usgs.gov/) to cover the entire study area, which is cloudless, enables simple processing and accurate classification (Table 1).
Table (1). List of Landsat Images

\begin{tabular}{lllll}
\hline \hline \multicolumn{5}{l}{ Satellite Images } \\
\hline \multirow{4}{*}{ Sen- } & Land- & Land- & Land- & Land- \\
sor & and & and & and & and \\
& TIRS) & TIRS) & TIRS) & TIRS) \\
Date & 2013.04 & 2014.06 & 2015.07 & 2016.07 \\
\hline
\end{tabular}

Each image has a spatial resolution of 30 meters, except for the panchromatic channel and the thermal-infrared bands, which have 15 and 100 meters resolution, respectively (Table 2 ).

Classification: Supervised classification was carried out for the years: April 2013, June 2014, July 2015, and July 2016. Ground control points, obtained using a Global Positioning System (GPS) from locations in relation to the classes of the study area, were plotted on Land sat 8 image, which was used to verify the training sites (defined classes) as regards the spectral signature. Supervised classification for the various classes was performed using finally maximum likelihood classification. For image classification, five classes were defined which are Burned area, Woodlands, Urban areas, Sea, Other uses.

Table (2). Landsat 8 band designations.

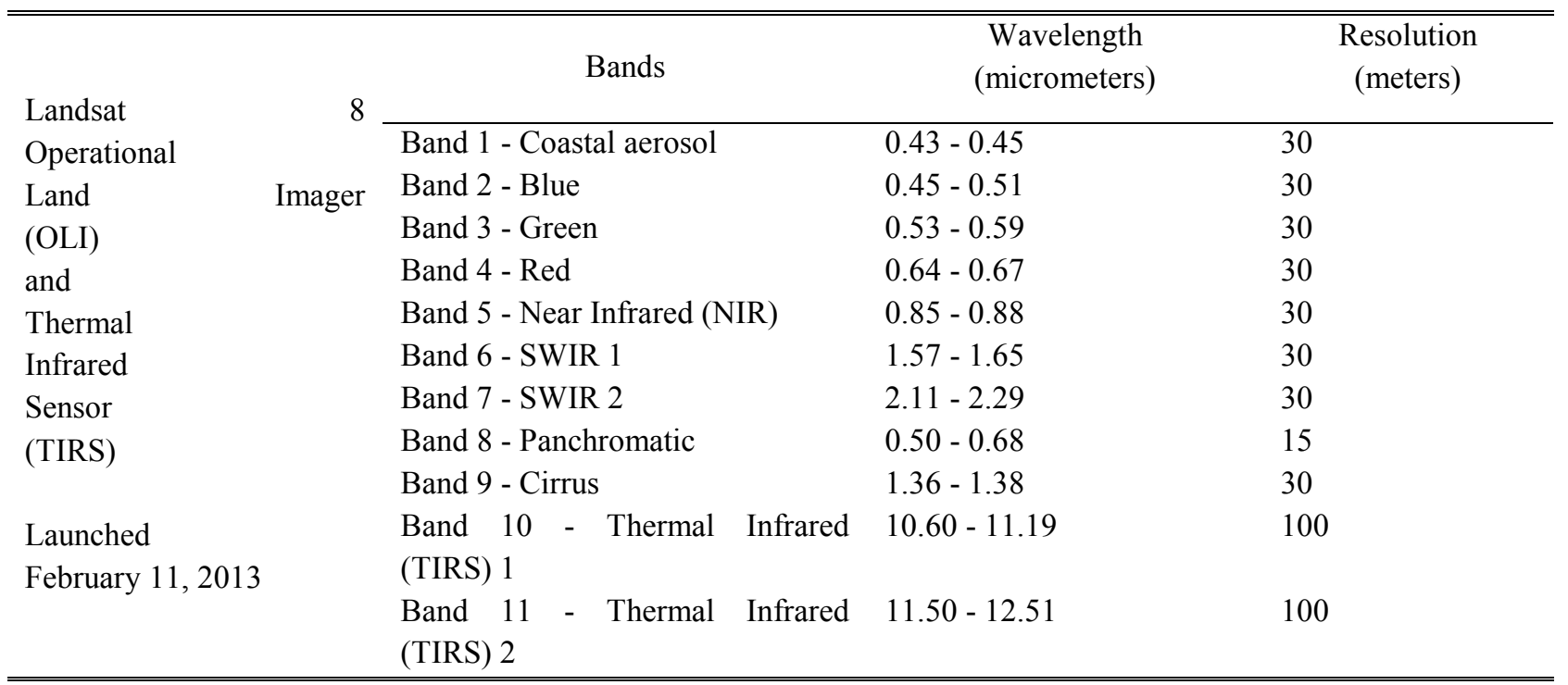


Assessment of Classification Results Using Error Matrix The error matrix-based accuracy assessment method is the most common and valuable method for the evaluation of change detection results. Thus, an error matrix and a Kappa analysis were used to assess change accuracy. Kappa analysis is a discrete multivariate technique used in accuracy assessments (Congalton \& Mead, 1983; Jensen, 1996).

\section{Normalized difference vegetation index}

(NDVI): NDVI is defined as the difference and ratio of reflection between visible ray and nearinfrared wavelength. In this study, it was used to detect the change of vitality with the spatial distribution of vegetation, which is calculated using the following equation.

$\mathrm{NDVI}=(N I R-R) /(N I R+R)=($ Band $5-$ Band 4) / (Band $5+$ Band 4).

Where:

NDVI - Normalized Difference Vegetation Index.

NIR - Near Infra-Red Band (band 5 Landsat 8 (OLI and TIRS).

$\mathrm{R}$ - Red spectral band (visible, Red-band 4 Landsat 8 (OLI and TIRS).

Normalized Burn Ratio (NBR): The formula is similar to NDVI, except that it uses nearinfrared (NIR) and shortwave-infrared (SWIR) wavelengths. The NBR was designed to highlight burned areas and estimate fire severity, which is calculated using the following equation.

$\mathrm{NBR}=(N I R-S W I R) /(N I R+S W I R)=($ Band $5-$ Band 7) / (Band 5+ Band 7).

Where:

NBR - Normalized Burning Ratio.

NIR - Near Infra-Red Band (band 5 Landsat 8 (OLI and TIRS).

SWIR - Short wave- Infrared band (band 7 Landsat 8 (OLI and TIRS).

The Digital Elevation Model (DEM): The Digital Elevation Model (DEM) - SRTM-30m data was downloaded from the website (http://www.diva-gis.org/gdata).Altitude, slope, and aspect are among the most important data

in many natural resources. Elevation, slope, and aspect were derived from DEMs and used with other spatial data.

The digital image-processing software Envi5 was used for the processing, analysis, and integration of spatial data to reach the objectives of the study. The GIS software is used to assist planners in the analysis of such changes, by combining the maps derived from the classified images and integrating the multiple databases.

\section{RESULTS}

Classification: supervised classification of satellite images of April 2013, June 2014, July 2015, and July 2016 have shown clearly the amount of change in the land cover in the study area. For image classification, five classes were defined which are: Burned area, Woodlands, Urban areas, Sea, and, Other uses (Figure 2).

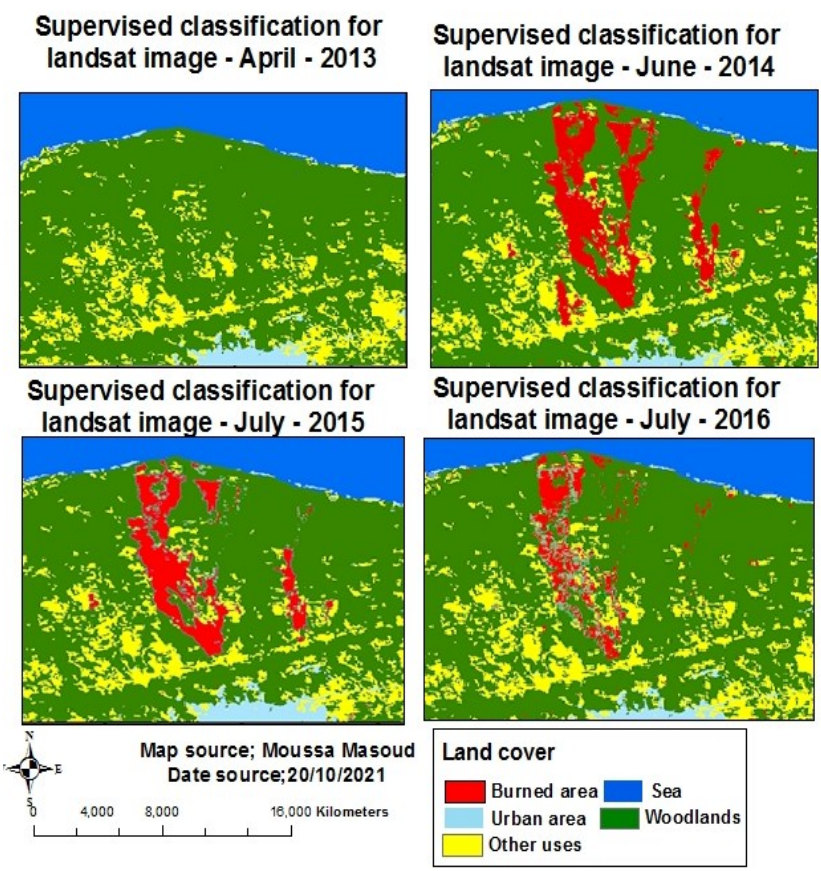

Figure: (2). Supervised classification of satellite images of Elwasita area in Al-Jabal Al-Akhdar for four years (April 2013, June 2014, July 2015, and July 2016).

The overall accuracy for the classified map based on the supervised classification was $90.3 \%$ which is considered good, and it is above the limit set by the USGS guidelines $(85 \%)$. Because the overall accuracy assessISSN: online 2617-2186 print 2617-2178 
ment tends to overestimate the actual performance, a more useful representation of performance is the Kappa coefficient (Cohen, 1960). The Kappa coefficient for the supervised image was 0.811 , which means that $81.1 \%$ of the classification is better than a random classification.
This is considered good because a Kappa value above $80 \%$ is considered to have a strong agreement (Manandhar et al., 2009). Table 3 shows the results for the accuracy assessment for the supervised classification of the classified image.

Table(3). Matrixes of changes (Square $\mathrm{Km}$ ) in land cover of classified map

\begin{tabular}{|c|c|c|c|c|c|c|c|}
\hline & Sea & Urban Area & Other Uses & Woodlands & $\begin{array}{c}\text { Burned } \\
\text { Area }\end{array}$ & Total & $\begin{array}{c}\text { Producer's } \\
\text { Accuracy }\end{array}$ \\
\hline Sea & 24377 & 55 & 1232 & 0 & 0 & 25664 & 94.98519 \\
\hline Urban Area & 0 & 520 & 45 & 110 & 2 & 677 & 76.80945 \\
\hline Woodlands & & 090.2 & 120 & 2409 & 5 & 2624.2 & 91.79941 \\
\hline Burned Area & 0 & 0 & 5 & 3 & 38.6 & 46.6 & 82.83262 \\
\hline Other Uses & 728 & 4 & 21452 & 20 & 3 & 22207 & 96.60017 \\
\hline Total & 25105 & 669.2 & 22854 & 2542 & 48.6 & 51218.8 & \\
\hline user's accuracy & 97.10018 & 77.70472 & 93.86541 & 94.7679 & 79.42387 & & \\
\hline
\end{tabular}

Average accuracy 88.57

Overall accuracy 90.3

Overall Kappa statistics $=0.811$

NDVI: The interpretation implies the delimitation of the areas in tones of different colors, which shows characteristics of the vegetation. NDVI was calculated for all the satellite images (Figure 3).

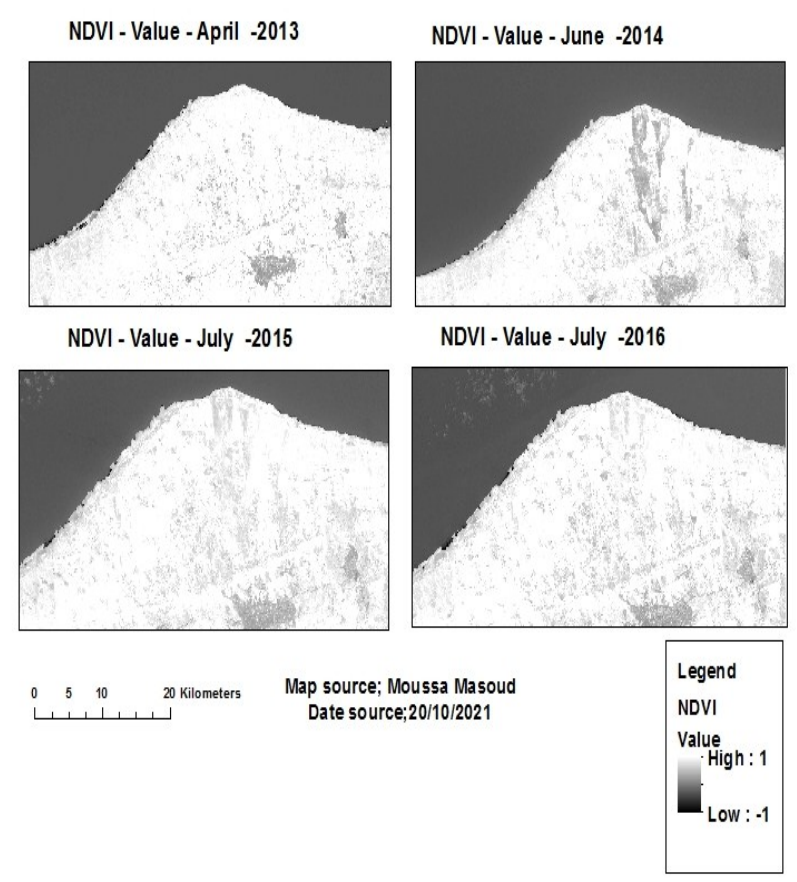

Figure: (3). Land covers change detection using NDVI.
NBR: One of the most widely used indexes for mapping burn severity is NBR, which combines the reflectance in the NIR and SWIR bands. NBR is a very sensitive index to emphasize burned areas and to determine the severity of the burns (Figure 4).

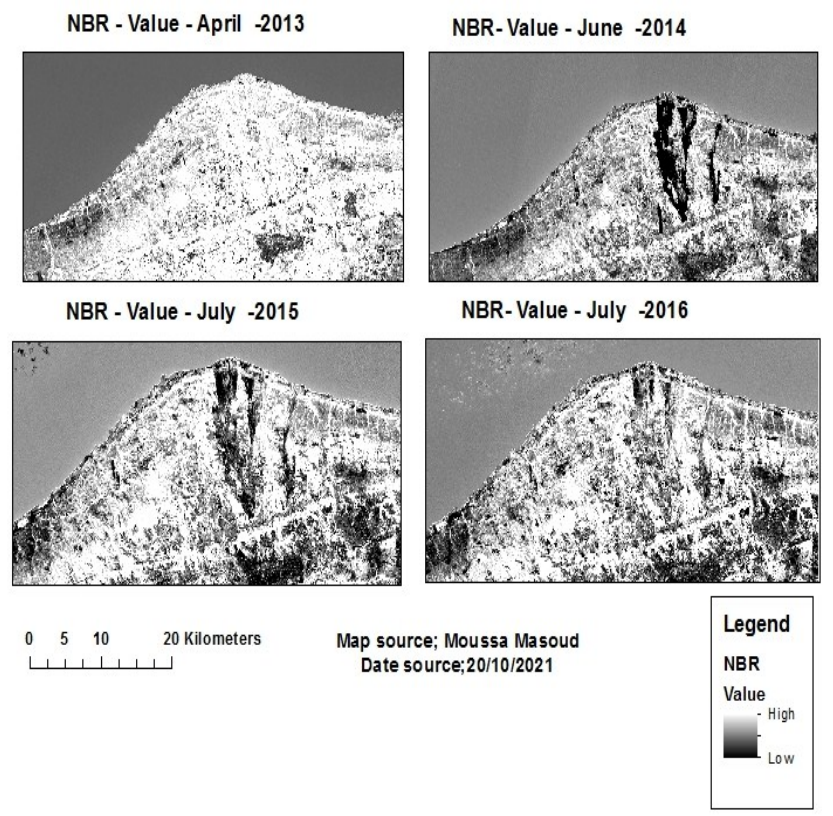

Figure: (4). Land covers change detection using NBR.

Slope: A slope is defined as the rate of change of elevation, expressed as a gradient in percentage or degrees. A slope map of the present 
study area was prepared from DEM in GIS. The slope of the present study has been divided into three classes, which were slightly inclined, inclined, and strongly inclined (Figure 5). The statistical analysis showed that fire was concentrated on the inclined sections in a proportion of $76 \%$, while $16 \%$ in strongly inclined, and $8 \%$ slightly inclined (Table 4 ). The results do not show any relationship between fires and slopes, but this may be due to the nature of the area exposed to fire and does not prove that there is no relationship.

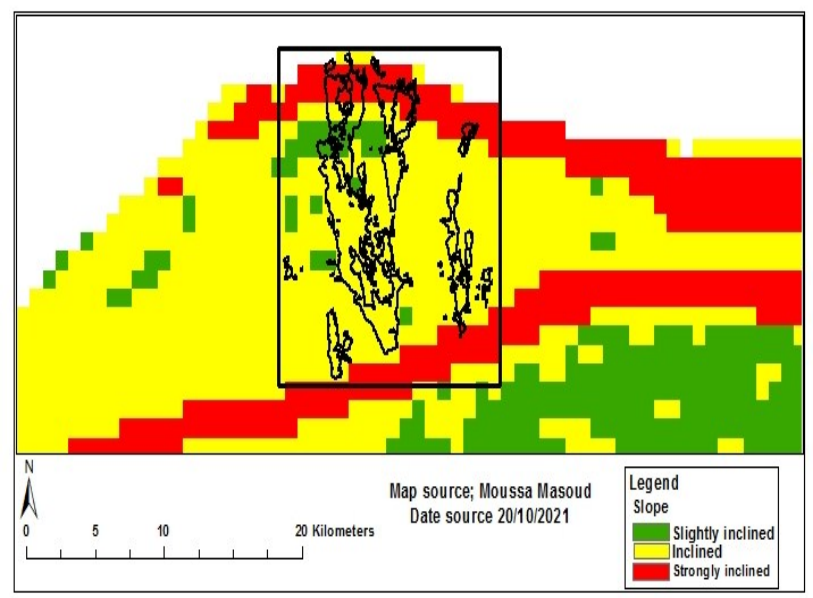

Figure: (5). Map of the inclinations.

Table (4). Percentage of burned areas on the altitude, slope, and aspect.

\begin{tabular}{cccccc}
\hline \hline $\begin{array}{c}\text { Slightly in- } \\
\text { clined }\end{array}$ & $8 \%$ & $\begin{array}{c}\text { North } \\
\text { West }\end{array}$ & $47 \%$ & $0-200 \mathrm{~m}$ & $\begin{array}{c}20 \\
\%\end{array}$ \\
\hline Inclined & 76 & North & $29 \%$ & $\begin{array}{c}200- \\
450 \mathrm{~m}\end{array}$ & $\begin{array}{c}80 \\
\%\end{array}$ \\
$\begin{array}{c}\text { Strongly in- } \\
\text { clined }\end{array}$ & $\begin{array}{c}16 \\
\%\end{array}$ & $\begin{array}{c}\text { North } \\
\text { East }\end{array}$ & $12 \%$ & $\begin{array}{c}\text { Above } \\
450 \mathrm{~m}\end{array}$ & 0 \\
\hline \hline
\end{tabular}

Aspect: Aspect is the steepest downslope direction from each cell to its neighbors. It can be thought of as the direction of a slope or the compass direction a hill faces. According to a degree of a slope, its direction is categorized into nine classes (Figure 6). The results have found they mainly oriented towards NW (47\%), N (29\%), and NE (12\%) slope orientation (Table 4). The results found that the areas most exposed to fire are the northeastern aspect, followed by the northern aspect.

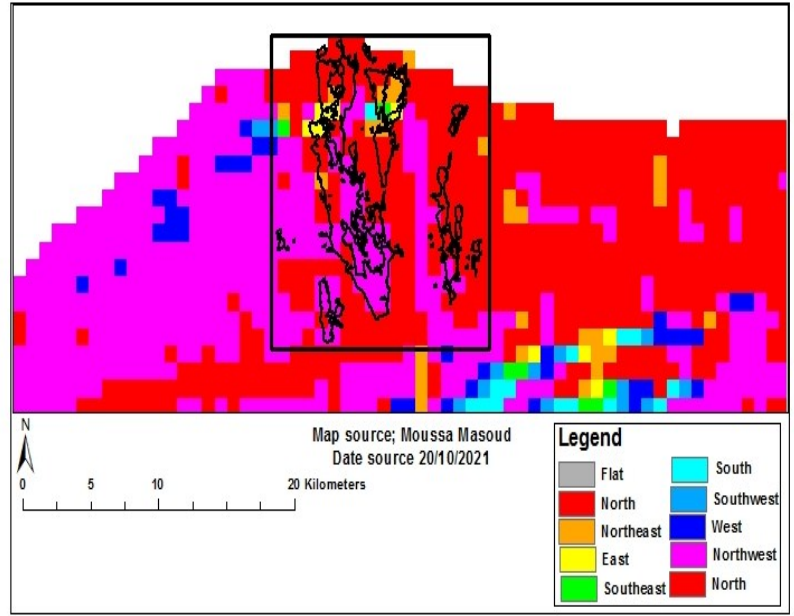

Figure: (6). Map of slopes exposure.

Altitude: Another element with an important role in analyzing forest fire is altitude; because it determines the accessibility of affected areas for intervention, and high areas have a low degree of accessibility. In more detail, the altitude of the affected areas as defined in 3 classes are; between sea level to 864 meters (sea level to $200 \mathrm{~m}, 201-450$, and 451- 864) (Figure 7). Thus it was observed that the most affected areas were those between $200 \mathrm{~m}-450 \mathrm{~m}$, with a percentage of $80 \%$. Also affected were the classes from sea level to $200 \mathrm{~m}$ in a proportion of $20 \%$, while the area between $451-864 \mathrm{~m}$ was free of fire (Table 4).

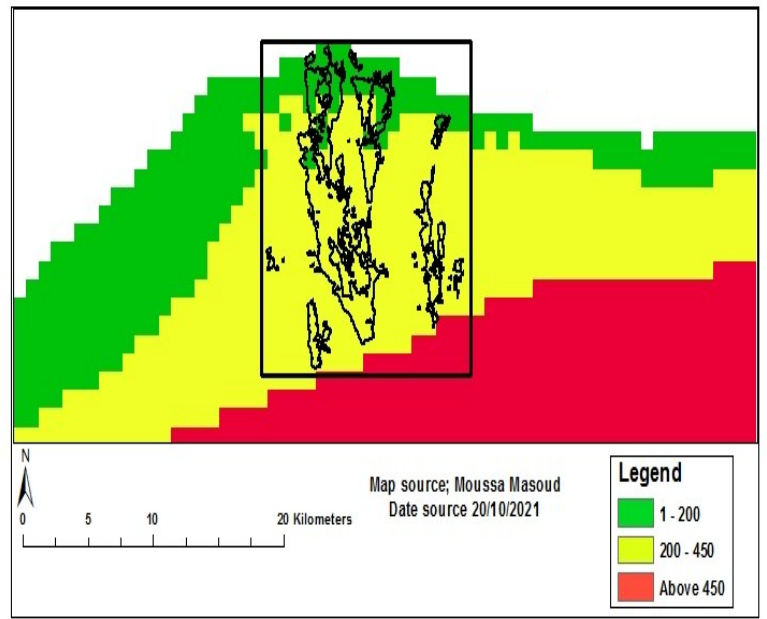

Figure: (7). Altitude map of the three categories.

\section{DISCUSSION}


Post-fire monitoring in the Elwasita area was achieved using supervised classifications, NDVI, and NBR. The results explain how remote sensing can be applied to estimate, observe, and quantify post-fire in a massive zone where traditional procedures (such as field observation) may not be possible.

In this study, land cover classification images for four years $(2013,2014,2015$, and 2016) were carried out. The results have found that burned areas decreased. On the other hand, the woodland area increased. This indicates the natural recovery of woodlands with time. Especially it was concluded that the amount of recovery increased significantly from 2013 to 2016 (Figure2).

Numerous studies found that the NBR is the most effective index for burn severity. The NBR is estimated as the difference between near-infrared (NIR) and short-wave infrared (SWIR) reflectance divided by their sum (Key $\&$ Benson, 2005). The NDVI is another widely utilized index that is an indicator of plant greenness, measuring plant type, and amount on land surfaces. Many studies have used NDVI to monitor post-fire vegetation dynamics in the Mediterranean region (Mitri \& Gitas, 2010; Petropoulos et al., 2014; Veraverbeke et al., 2010).

The results have shown NDVI images are the most useful to quantify the difference in photosynthetically active vegetation. Not only can a distinct presence and absence within the perimeter be determined by looking at the images, but it is also easy to generate charts using the information provided by the image. Figure 3 shows the difference in the average NDVI values in the two subsets; burned and unburned area for four years. The highest values of NDVI (0.75 - 2013, 0.51 - 2014, 0.63 -2015, $0.72-2016$ ) are correspondent to the tones of white and reach up to 1 . These are associated with the thickest and healthiest forests. The darkest tones, close to black, show the exact opposite of what was mentioned above. The lack of vegetation, chlorophyll, is expressed by the bare soil or rock, which absorb the nearinfrared more.

NDVI has been confirmed to be specifically sufficient to estimate post-fire recovery of Mediterranean ecosystems (Díaz-Delgado et al., 1998; Fox et al., 2008; Gouveia et al., 2010; Hope et al., 2007) as well as to observe vegetation dynamics subject to stress conditions such as those associated to major drought situations (Gouveia et al., 2009). Some authors (Epting \& Verbyla, 2005; Kokaly et al., 2007; Miller et al., 2009; Miller \& Thode, 2007) have successfully estimated burn severity established on temporal changes between pre and post-fire satellite imagery, namely by using differences of pre-and-post-fire NDVI values (De Santis \& Chuvieco, 2007; Fox et al., 2008).

The NBR index displayed itself to be more critical to the pre-/post-fire displacements of the pixels influenced by the fire in the MIR-NIR space than the NDVI in the R-NIR space. Healthy vegetation shows a very high reflectance in the NIR, and low reflectance in the SWIR portion of the spectrum. The opposite of what is seen in areas devastated by fire. Both indices were hardly sensitive to the pre-/postfire spectral changes corresponding to the unaffected pixels attributable to "perturbing factors'. The pre-/post-fire indices are the most appropriate ones for holding out the discrimination between pixels not burned by a fire and pixels affected by a fire. The results showed that there was a slight difference in the vegetation recovery rate measured by the NBR between the different years with NDVI.

Furthermore, it is worth noting the greater capacity of the NBR to determine fire severity levels, which is in agreement with the results of previous works that compare NBR and NDVI (Pereira, 1999). The effective use of altitude information can detect physical conditions on the land that may increase or decrease a property's risk of natural hazards (Figure 7). It is observed that the most affected areas are those 
between $200 \mathrm{~m}-450 \mathrm{~m}$, with a burned area percentage of $80 \%$. Also, a visual interpretation of the relationships between woodlands recovery and topography are presented in Figures 5, 6, and 7 respectively. Comparing the two index results, it can be seen that stronger recovery dynamics appeared to occur in the northwest and north of the burn area. It is common with other studies and many authors; finding that recovery was better on north-facing slopes compared to south-facing slopes related to northern hemisphere dynamics (Fox et al., 2008). This fact reveals that vegetation recovery dynamics following a forest fire event take a long time.

This study was aimed towards showing that remote sensing is a helpful management tool and that quantifiable data could be taken from the images using basic image enhancements and simple band math. Demonstrating that a land manager could manipulate images and can monitor landscape level changes. By using remotely sensed imagery in a more common pattern, managers could keep resources by performing small field studies to get precise data on the rate of change. Remote sensing has been perceived to be a robust tool to observe post-fire vegetation recovery over different regions (Epting \& Verbyla, 2005; Goetz et al., 2006) that include Mediterranean ecosystems (Minchella et al., 2009; Röder et al., 2008). The method established on remote sensing has also been successfully utilized to evaluate fire risk (Chuvieco et al., 2010), burn severity (De Santis \& Chuvieco, 2007; Epting \& Verbyla, 2005; Fox et al., 2008; Kokaly et al., 2007; Miller et al., 2009; Miller \& Thode, 2007) and erosion risk (Fox et al., 2008).

Future studies in this area should include using more study areas with different types of and vegetation to accurately display the extent to which NDVI and NBR can be used. Another suggestion would be to study the meteorological indicator effect to enclose the entire perimeter of the fire using remote sensing and GIS.

\section{CONCLUSION}

NDVI, NBR, supervised classification, aspect, slope, and altitude images were used to determine the fire severity and vegetation recovery of the study area. Analysis showed that it mainly oriented towards the northwest (47\%), north $(29 \%)$, and northeast (12\%). The statistical analysis showed that fire was concentrated on the inclined in a proportion of $76 \%$, and the most affected areas are those between $200 \mathrm{~m}$ $450 \mathrm{~m}$ above sea level, with a percentage of $80 \%$.

\section{REFERENCES}

Alacantara, E. (2010). A lonely rooster cannot bring on a new dawn: the role of a FL teachers' association in the professional development of its associates'. Unpublished MA dissertation, Universidade de Brasília, Instituto de Letras, Brazil .

Arnan, X ‘.Rodrigo, A., \& Retana, J. (2007). Post - fire regeneration of Mediterranean plant communities at a regional scale is dependent on vegetation type and dryness. Journal of Vegetation Science, 18(1), 111-122 .

Bond, W. J., Woodward, F. I., \& Midgley, G. F .2005) .The global distribution of ecosystems in a world without fire. New phytologist, 165(2), 525-538.

Carrion, J. S., Sánchez-Gomez, P., Mota, J. F., Yll, R., \& Chaín, C. (2003). Holocene vegetation dynamics, fire and grazing in the Sierra de Gádor, southern Spain. The Holocene, 13(6), 839-849 .

Chuvieco, E., Aguado, I., Yebra, M., Nieto, H., Salas, J., Martín, M. P., Vilar, L., Martínez, J., Martín, S., \& Ibarra, P. (2010). Development of a framework for fire risk assessment using remote sensing and geographic information 
system technologies. Ecological Modelling, 221(1), 46-58 .

Cocke, A. E., Fulé, P. Z., \& Crouse, J. E. (2005). Comparison of burn severity assessments using Differenced Normalized Burn Ratio and ground data. International Journal of Wildland Fire, 14(2), 189-198.

Cohen, J. (1960). A coefficient of agreement for nominal scales. Educational and psychological measurement, 20(1), 3746 .

Congalton, R. G., \& Mead, R. A. (1983). A quantitative method to test for consistency and correctness in photointerpretation. Photogrammetric Engineering and Remote Sensing, 49(1), 69-74.

De Santis, A., \& Chuvieco, E. (2007). Burn severity estimation from remotely sensed data: Performance of simulation versus empirical models. Remote Sensing of Environment, 108(4), 422435 .

Díaz-Delgado, R., Salvador, R., \& Pons, X. (1998). Monitoring of plant community regeneration after fire by remote sensing. Fire management and landscape ecology, 315-324 .

Epting, J., \& Verbyla, D. (2005). Landscapelevel interactions of prefire vegetation, burn severity, and postfire vegetation over a 16-year period in interior Alaska. Canadian Journal of Forest Research, 35(6), 1367-1377 .

Eva, H., \& Lambin, E. (1998). Burnt area mapping in Central Africa using ATSR data .International Journal of Remote Sensing, 19(18), 3473-3497 .
Fox, D., Maselli, F., \& Carrega, P. (2008). Using SPOT images and field sampling to map burn severity and vegetation factors affecting post forest fire erosion risk. Catena, 75(3), 326-335 .

Goetz, S. J., Fiske, G. J., \& Bunn, A. G. (2006). Using satellite time-series data sets to analyze fire disturbance and forest recovery across Canada. Remote Sensing of Environment, 101(3), 352365 .

Gouveia, C., DaCamara, C., \& Trigo, R. (2010). Post-fire vegetation recovery in Portugal based on spot/vegetation data. Natural Hazards and Earth System Sciences, 10(4), 673-684 .

Gouveia, C., Trigo, R., \& DaCamara, C. (2009). Drought and vegetation stress monitoring in Portugal using satellite data. Natural Hazards and Earth System Sciences, 9(1), 185-195.

Hope, A., Tague, C., \& Clark, R. (2007). Characterizing post - fire vegetation recovery of California chaparral using $\mathrm{TM} / \mathrm{ETM}+$ time - series data. International Journal of Remote Sensing, 28(6), 1339-1354.

Jakubauskas, M. E., Lulla, K. P., \& Mausel, P. W. (1990). Assessment of vegetation change in a fire-altered forest landscape. PE\&RS, Photogrammetric Engineering \& Remote Sensing, 56(3), 371-377.

Jensen, J. R. (1996). Introductory image processing: A remote sensing perspective. Prentic Hall .

Kazanis, D., \& Arianoutsou, M. (2004). Factors determining low Mediterranean ecosystems resilience to fire: the case of Pinus halepensis forests. Proceedings of 10th MEDECOS conference ، 
Key, C., \& Benson, N .(2005) .Landscape assessment: ground measure of severity, the composite burn index; and remote sensing of severity, the normalized burn ratio. FIREMON: Fire effects monitoring and inventory system, 2004 .

Kokaly, R. F., Rockwell, B. W., Haire, S. L., \& King, T. V. (2007). Characterization of post-fire surface cover, soils, and burn severity at the Cerro Grande Fire, New Mexico, using hyperspectral and multispectral remote sensing. Remote Sensing of Environment, 106(3), 305325 .

Landmann, T. (2003). Characterizing sub-pixel Landsat ETM+ fire severity on experimental fires in the Kruger National Park, South Africa. South African Journal of Science, 99(7), 357360 .

Maheras, G. (2002). Forests fires in Greece. The analysis of the phenomenon affecting both natural and human environment. The role of sustainable development in controlling fire effects M. Sc. Thesis.

Manandhar, R., Odeh, I. O., \& Ancev, T. (2009). Improving the accuracy of land use and land cover classification of Landsat data using post-classification enhancement. Remote Sensing, 1(3), 330-344 .

Masoud, Moussa. (2015) Monitoring land use /land cover using multi-temporal Landsat images in Al-Jabal Al-Akhdar area in Libya between 1984 and 2003. Al-Mukhtar Journal of Sciences Vol (31), No. (01), Year (2016) 12-22.

Masoud, Moussa. \& Alajeel, Khamees. (2016). Forest fires study using satellite imagery and GIS: a case study of AlJabal Al-Akhdar area in Libya.
Proceedings of the fourth scientific conference of environment and sustainable development in the arid and semiarid regions (ICESD), from 20-22 November. Ajdabiya. Libya.

Miller, J. D., Safford, H., Crimmins, M., \& Thode, A. E. (2009). Quantitative evidence for increasing forest fire severity in the Sierra Nevada and southern Cascade Mountains, California and Nevada, USA. Ecosystems, 12(1), 16-32.

Miller, J. D., \& Thode, A. E. (2007). Quantifying burn severity in a heterogeneous landscape with a relative version of the delta Normalized Burn Ratio (dNBR). Remote Sensing of Environment, 109(1), 66-80 .

Minchella ‘A., Del Frate, F., Capogna, F., Anselmi, S., \& Manes, F. (2009). Use of multitemporal SAR data for monitoring vegetation recovery of Mediterranean burned areas. Remote Sensing of Environment, 113(3), 588597.

Mitri, G. H., \& Gitas, I. Z. (2010). Mapping postfire vegetation recovery using EO-1 Hyperion imagery. IEEE Transactions on Geoscience and Remote Sensing, 48(3), 1613-1618 .

Pausas, J., \& Verdú, M. (2005). Plant persistence traits in fire - prone ecosystems of the Mediterranean basin: a phylogenetic approach. Oikos, 109(1), 196-202 .

Pausas, J. G. (2004). Changes in fire and climate in the eastern Iberian Peninsula (Mediterranean basin). Climatic change, 63(3), 337-350 . 
Pereira, J. M. (1999). A comparative evaluation of NOAA/AVHRR vegetation indexes for burned surface detection and mapping. IEEE Transactions on Geoscience and Remote Sensing, 37(1), 217-226.

Petropoulos, G. P., Griffiths, H. M., \& Kalivas, D. P. (2014). Quantifying spatial and temporal vegetation recovery dynamics following a wildfire event in a Mediterranean landscape using EO data and GIS. Applied Geography, 50, 120131 .

Röder, A., Hill, J., Duguy, B., Alloza, J. A., \& Vallejo, R. (2008). Using long time series of Landsat data to monitor fire events and post-fire dynamics and identify driving factors. A case study in the Ayora region (eastern Spain). Remote Sensing of Environment, 112(1), 259-273.

Rodrigo, A., Retana, J., \& Picó, F. X. (2004). Direct regeneration is not the only response of Mediterranean forests to large fires. Ecology, 85(3), 716-729 .

Roy, D. P., \& Landmann, T. (2005). Characterizing the surface heterogeneity of fire effects using multi - temporal reflective wavelength data. International Journal of Remote Sensing, 26(19), 4197-4218 .

Smith, A. M., \& Hudak, A. T. (2005). Estimating combustion of large downed woody debris from residual white ash. International Journal of Wildland Fire, 14(3), 245-248 .

Smith, A. M., Wooster, M. J., Drake, N. A., Dipotso, F. M., Falkowski, M. J., \& Hudak, A. T. (2005). Testing the potential of multi-spectral remote sensing for retrospectively estimating fire severity in African Savannahs.
Remote Sensing of Environment, 97(1), 92-115.

Stroppiana, D., Pinnock, S., Pereira, J. M., \& Grégoire, J.-M. (2002). Radiometric analysis of SPOT-VEGETATION images for burnt area detection in Northern Australia. Remote Sensing of Environment, 82(1), 21-37.

Tishkov, A. A. (2004). Forest fires and dynamics of forest cover. Natural Disasters-Volume II, 130 .

Trigg, S., \& Flasse, S. (2000) Characterizing the spectral-temporal response of burned savannah using in situ spectroradiometry and infrared thermometry. International Journal of Remote Sensing, 21(16), 3161-3168 .

Veraverbeke, S., Verstraeten, W. W., Lhermitte, S., \& Goossens 'R. (2010). Evaluating Landsat Thematic Mapper spectral indices for estimating burn severity of the 2007 Peloponnese wildfires in Greece. International Journal of Wildland Fire, 19(5), 558569 .

White, J. D., Ryan, K. C., Key, C. C., \& Running, S. W. (1996) Remote sensing of forest fire severity and vegetation recovery. International Journal of Wildland Fire, 6(3), 125-136. 


\section{تجدد الغطاء النباتي بعد الحريق في منطقة الوسيطة بالجبل الأخضر - ليبيا - بناءً على معلومات الاستثعار عن بعد}

موسي جبريل محمد مسعود

قسم الغابات والمراعي، كلية الموارد الطبيعية وعلوم البيئة، البيضاء، ليبيا.

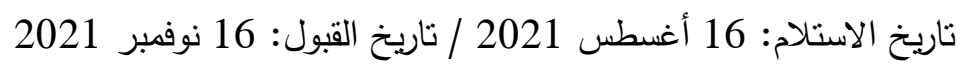
https://doi.org/10.54172/mjsc.v36i4.588:Doi

المستخلص: تقتيات الاستشعار عن بعد المعتمدة على الأقمار الصناعية، وأنظمة المعلومات الجغرافية (GIS) تقدم حلولا قابلة للتتغيل، وفعالة من حيث التكلفة لرسم خرائط الحرائق، ومراقبة التجدد بعد الحرائق. تم اختيار حريق الوسيطة، الذي حدث خلال شهري أبريل ومايو في عام 2013 في ليبيا، موقعا للاراسة. تهدف هذه الدراسة إلى مراقبة استعادة الغطاء النباتي، والتحقيق في تئي العلاقة بين استعادة الغطاء النباتي، والعوامل الطبوغرافية باستخدام المؤشرات الطيفية المتعددة مـع بعض العضيل العوامل الطبوغرافية. تم

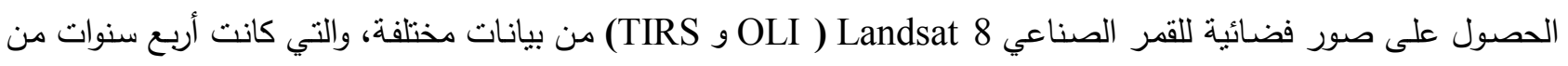
أبريل 2013، يونيو 2014، يوليو 2015، و يوليو 2016، لتقييم شدة الحريق باستخدام نسبة الحرق الطبيعي المستخدمة على لى

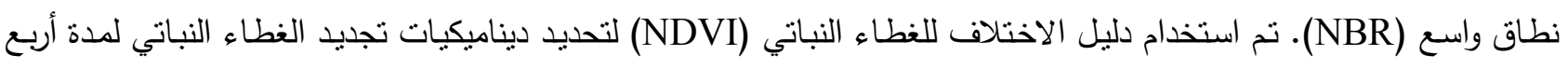
سنوات متتالية. تم استخدام التصنيف المراقب بنجاح لتحديد المنطقة التي تعرضت للحريق، ومقدار التجدد الطبيعي بعد ذلك. بالإضافة إلى ذلك، تم استخدام كلا من الارتفاع، والانحدار، والجوانب المستمدة من نموذج الارتفاع الرقمي (DEM) لتحديد شدة

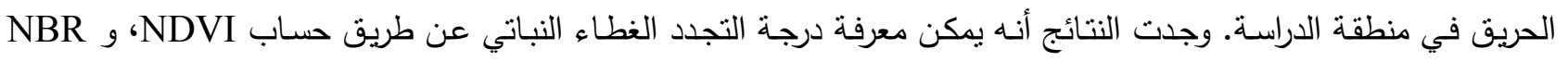
باستخدام صور Landsat 8 OLI, TIRS. أظهر التحليل أنه موجه بشكل رئيسي نحو الثمال الغربي (47\%)، الثمال (29٪)، والشمال الشرقي (12\%). وأظهر التحليل الإحصائي أن الحريق نركز على منحدر بنسبة 76٪، وأكثر المناطق تضررا هي تلك

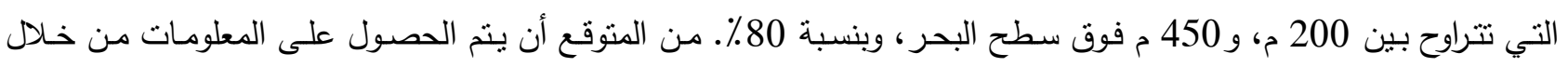
بيانات الأقمار الصناعية المختلفة، والغابات الرقمية. تعمل هذه الدراسة كنافذة لفهم عملية شدة الحرائق، واستعادة الغطاء النباتي الذي يعد أمرًا حيويًا في أنظمة إدارة حرائق الغابات.

الكلمات المفتاحية: نظم المعلومات الجغرافية، دليل الاختلاف للغطاء النباتي، نسبة الحرق الطبيعي، صور الأقمار الصناعية. 